Case Report

\title{
Adrenal dysplasia in a young SD rat
}

\author{
Yuki Kato $^{1 *}$, Emi Kashiwagi1, Yoshiji Asaoka ${ }^{1}, K^{1}$ ae Fujisawa1, Noriko Tsuchiya ${ }^{1}$, \\ and Mikinori Torii ${ }^{1}$ \\ ${ }^{1}$ Drag Safety Evaluation, Research Laboratory for Development, Shionogi \& Co., Ltd., 3-1-1 Futaba-cho, Toyonaka, Osaka 561-0825, \\ Japan
}

\begin{abstract}
The present report describes an adrenal dysplasia in which developmental abnormality was observed in the adrenal gland of a six-week-old male $\mathrm{Crl}: \mathrm{CD}(\mathrm{SD})$ rat. Microscopically, a localized lesion composed of mildly vacuolated adrenal fasciculata cells with a slightly disturbed cord structure and containing areas with high cell density was observed in a unilateral adrenal gland; no macroscopical changes were detected in the organ. The areas with high cell density consisted of two cell types. One type included small cells with a round nucleus and acidophilic cytoplasm, and the cells were positive for steroidogenic factor-1 (SF-1) but negative for nestin. The other type of cells had a spindle to polygonal shape, clear nucleus, and a cytoplasm with an obscure boundary; the cells were positive for nestin but negative for SF-1, neuronal nuclear antigen, and chromogranin A. These results suggested that the former type of cells were adrenal cortex cells and that the latter were immature neuronal cells. Considering that immature adrenal cortex cells and neural crest cells (future adrenal medulla) are mixed during a stage in rat adrenal gland development, we concluded that the observed lesion was caused by developmental abnormality. To the best of our knowledge, this is the first report to describe dysplasia in rat adrenal glands. (DOI: 10.1293/tox.2018-0056; J Toxicol Pathol 2019; 32: 101-104)
\end{abstract}

Key words: developmental abnormality, ectoderm, mesoderm, nestin, steroidogenic factor-1

The adrenal glands are endocrine glands located close to the anterior pole of the kidneys that produce a variety of hormones including adrenaline and the steroids aldosterone and cortisol ${ }^{1}$. Reports on congenital lesions in adrenal glands of young rodents have been limited to the accessory adrenocortical tissue and cyst ${ }^{2-4}$. Adrenocortical dysplasia characterized by disordered morphogenesis of the adrenal cortex, which is caused by spontaneous autosomal recessive mutation, has also been reported in DW/J inbred mice 5 . The present report describes an adrenal dysplasia in which developmental abnormality was observed in the adrenal gland of a young $\mathrm{Crl}: \mathrm{CD}(\mathrm{SD})$ rat. To the best of our knowledge, this is the first report to describe dysplasia in rat adrenal glands.

A six-week-old male $\mathrm{Crl}: \mathrm{CD}(\mathrm{SD})$ rat (Charles River Laboratories Japan, Inc., Kanagawa, Japan), which was assigned to a vehicle control group, was sacrificed at the end of a four-day repeated-dose oral toxicity study. The rat was housed in a plastic cage in an environmentally controlled

Received: 12 October 2018, Accepted: 27 December 2018

Published online in J-STAGE: 26 January 2019

*Corresponding author: Y Kato

(e-mail: yuuki.katou@shionogi.co.jp)

(C2019 The Japanese Society of Toxicologic Pathology

This is an open-access article distributed under the terms of the Creative Commons Attribution Non-Commercial No Derivatives (by-nc-nd) License. (CC-BY-NC-ND 4.0: https:/
creativecommons.org/licenses/by-nc-nd/4.0/). room (room temperature, $23 \pm 3^{\circ} \mathrm{C}$; relative humidity, 30 $60 \%$; lighting cycle, $12 \mathrm{~h}$ light/ $12 \mathrm{~h}$ dark) and supplied a pellet diet and tap water ad libitum. All experimental procedures were conducted after the study was approved by the Institutional Animal Care and Use Committee at Shionogi Pharmaceutical Research Center.

Macroscopic changes were not detected in any organs including the adrenal glands. The adrenal glands of the rat were fixed in $10 \%$ neutral buffered formalin and embedded in paraffin. A 3- $\mu \mathrm{m}$ section of the adrenal gland was stained with hematoxylin and eosin using a routine method. Chromogranin A, neuronal nuclear antigen (NeuN), steroidogenic factor-1 (SF-1), nestin, and Ki-67 were selected for immunohistochemical study. The immunohistochemical staining conditions are detailed in Table 1. Briefly, sections of adrenal glands were deparaffinized, hydrated, and blocked for endogenous peroxidase. Heat-induced epitope retrieval was performed for all antibodies except NeuN. Primary antibodies were incubated with the tissue samples overnight at $4^{\circ} \mathrm{C}$. Next, the sections were incubated with a horseradish peroxidase-conjugated polymer (Histofine Sample Stain MAXPO; Nichirei Biosciences, Tokyo, Japan) as the secondary antibody. For visualization, the sections were incubated with 3,3'-diaminobenzidine solution (Histofine SAB-PO [M] kit, Nichirei Biosciences) and then counterstained with hematoxylin.

Microscopically, a localized lesion composed of mildly vacuolated adrenal fasciculata cells with a slightly disturbed cord structure was observed in a unilateral adrenal gland, 
Table 1. Immunohistochemical Methods for the Analysis of Adrenal Dysplasia

\begin{tabular}{|c|c|c|c|c|c|}
\hline Primary antibody & Source1) & Type of antibody & Dilution2) & Antigen retrieval & $\begin{array}{c}\text { Target cell } \\
\text { (staining in normal adrenal gland) }\end{array}$ \\
\hline Chromogranin A & Abcam & $\begin{array}{l}\text { Rabbit polyclonal } \\
\text { (ab15160) }\end{array}$ & $1 / 500$ & $\begin{array}{c}\text { Boiled with citrate buffer } \\
\text { (pH 6.0) }\end{array}$ & $\begin{array}{c}\text { Endocrine cell } \\
\text { (positive for medulla cell) }\end{array}$ \\
\hline $\mathrm{NeuN}$ & Abcam & $\begin{array}{l}\text { Rabbit monoclonal } \\
\text { (EPR12763) }\end{array}$ & $1 / 1,000$ & $\begin{array}{l}\text { Boiled with antigen activation } \\
\text { solution, pH 9.0 (DAKO) }\end{array}$ & $\begin{array}{l}\text { Mature neuron } \\
\text { (positive for medulla cell) }\end{array}$ \\
\hline SF-1 & $\begin{array}{c}\text { Perseus } \\
\text { Proteomics }\end{array}$ & $\begin{array}{l}\text { Mouse monoclonal } \\
\quad(\mathrm{PP}-\mathrm{N} 1650-00)\end{array}$ & $1 / 100$ & $\begin{array}{l}\text { Boiled with citrate buffer } \\
\text { (pH 6.0) }\end{array}$ & $\begin{array}{c}\text { Steroidogenic cell } \\
\text { (positive for cortex cell) }\end{array}$ \\
\hline Nestin & Millipore & $\begin{array}{l}\text { Rabbit polyclonal } \\
\text { (rat-401) }\end{array}$ & $1 / 500$ & No treatment & $\begin{array}{l}\text { Mainly immature neuronal cell } \\
\text { (weakly positive for endothelial cell) }\end{array}$ \\
\hline $\mathrm{Ki}-67$ & DAKO & $\begin{array}{l}\text { Mouse monoclonal } \\
\text { (M7248) }\end{array}$ & $1 / 50$ & $\begin{array}{l}\text { Boiled with citrate buffer } \\
\qquad(\mathrm{pH} \mathrm{6.0)}\end{array}$ & $\begin{array}{l}\text { Proliferating cell } \\
\text { (mainly positive for cells between } \\
\text { the glomerulosa and fasciculata zones) }\end{array}$ \\
\hline
\end{tabular}

1)Abcam (Cambridge, UK), Perseus Proteomics (Tokyo, Japan), Millipore (Billerica, MA, US), and DAKO (Glostrup, Denmark). ${ }^{2)}$ These primary antibodies were diluted using Antibody Diluent with Background Reducing Components (DAKO). NeuN, neuronal nuclear antigen; SF-1, steroidogenic factor-1. The immunostaining method using SF-1 antibody was in accordance with the previous report of Furukawa $\mathrm{S}$ et al. ${ }^{6}$.
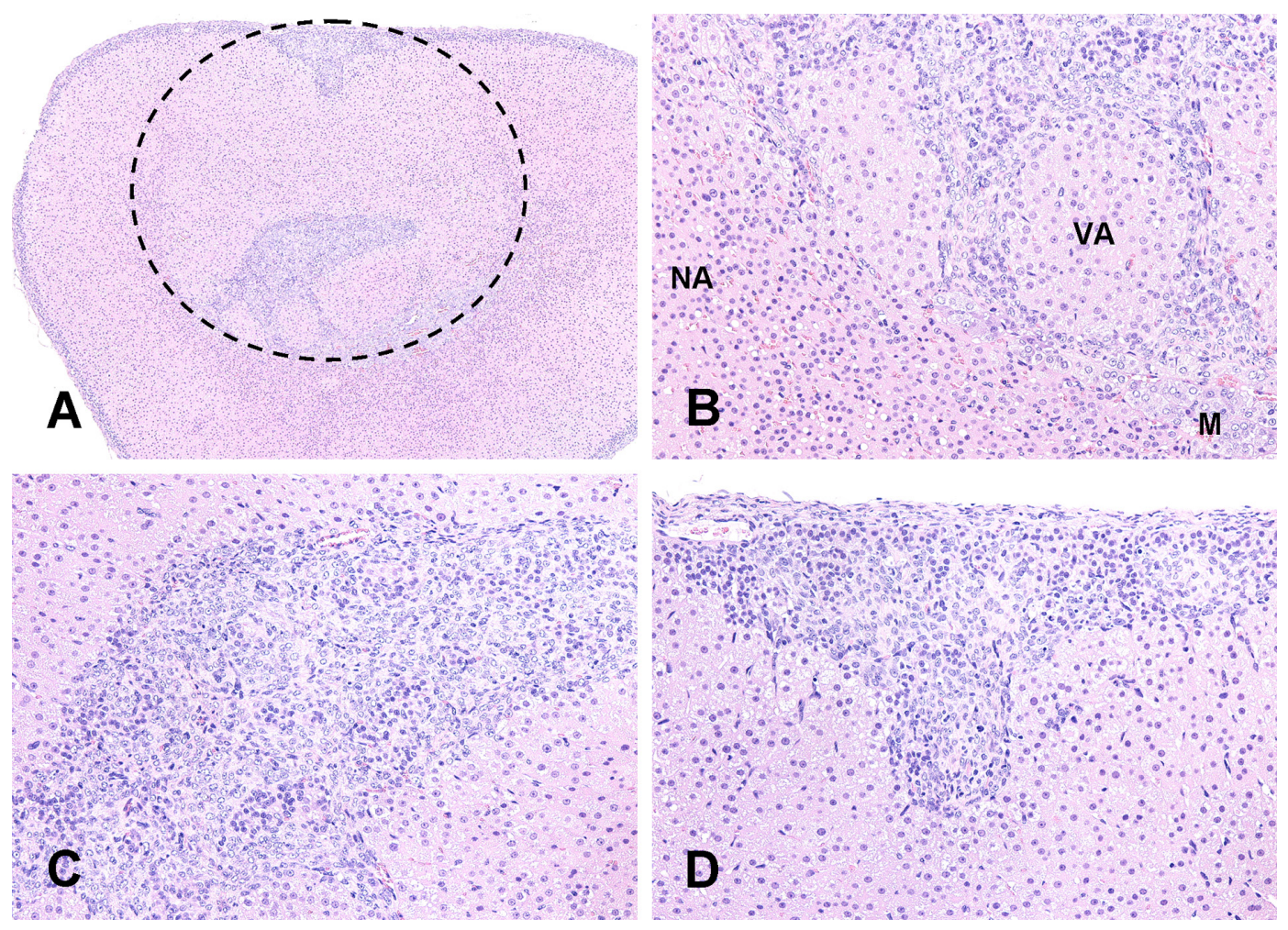

Fig. 1. Hematoxylin and eosin staining of dysplasia in the adrenal gland. A localized lesion composed of mildly vacuolated adrenal fasciculata cells was observed in a unilateral adrenal gland, where the lesion was slightly compressing the surrounding tissue (A and B). The lesion contained two areas with high cell density: one in the subcapsular region and one adjacent to the medulla (A). The area with high cell density adjacent to the medulla consisted of small cells with a round nucleus and acidophilic cytoplasm and cells with a spindle to polygonal shape, clear nucleus, and cytoplasm with an obscure boundary (C). The area with high cell density in the subcapsular region mainly consisted of the latter cell type (D). NA, normal area; VA, vacuolated area; M, medulla. Magnification: 40× (A), 100× (B), 200× (C, D).

where the lesion was slightly compressing the surrounding tissue (Fig. 1A and B). The lesion contained two areas with high cell density: one in the subcapsular region and one adjacent to the medulla (Fig. 1A). Both areas with high cell density consisted of cells with a spindle to polygonal shape, clear nucleus, and cytoplasm with an indistinct boundary, and the area adjacent to the medulla contained cells that were small with a round nucleus and acidophilic cytoplasm (Fig. 1C and D). This high cell density area and the adrenal medulla were clearly compartmentalized by the fibrous capsule (Fig. 1B). Careful observations revealed no continuity of the areas with high cell density between the medulla side and capsule side.

The Ki-67 index of the region with high cell densi- 


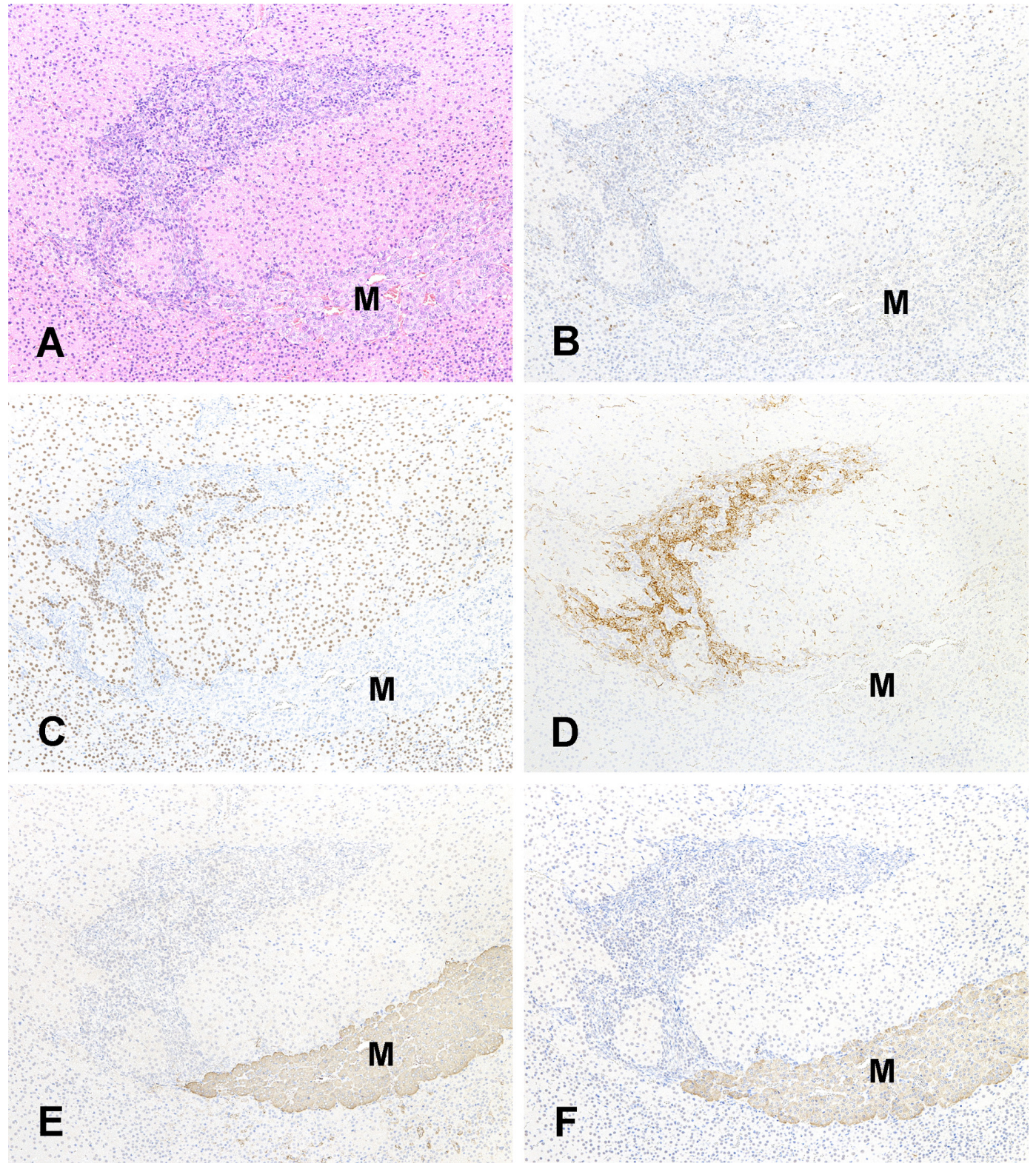

Fig. 2. Hematoxylin and eosin staining (A) and immunostaining for Ki-67 (B), steroidogenic factor-1 (SF-1) (C), nestin (D), chromogranin A (E), and neuronal nuclear antigen (NeuN) (F) of dysplasia in the adrenal gland. The Ki-67 index of the high cell density region was nearly identical to that of the surrounding normal fasciculata cells (A and B). The small cells with a round nucleus and acidophilic cytoplasm were positive for SF-1 and negative for nestin, whereas the cells with a spindle to polygonal shape, clear nucleus, and cytoplasm with an obscure boundary were positive for nestin and negative for SF-1, chromogranin A, and NeuN (C and F). Endothelial cells of the adrenal cortex were also weakly positive for nestin (D). M, medulla. Magnification: 200× (A-F).

ty was nearly identical to that of the surrounding normal fasciculata cells (Fig. 2A and B). Immunohistochemistry demonstrated that small cells with a round nucleus and acidophilic cytoplasm were positive for SF-1 and negative for nestin, whereas the cells with a spindle to polygonal shape, clear nuclei, and a cytoplasm with an obscure boundary were positive for nestin and negative for SF-1 in the region of high cell density on the medulla side (Fig. 2C and D). Both types of cells were negative for chromogranin A and NeuN (Fig. 2E and F). These results suggested that the small cells with a round nucleus were steroidogenic cells and that the cells with a spindle to polygonal shape and clear nucleus were immature neuronal cells.

The adrenal gland develops from two distinct cell populations ${ }^{5}$. The adrenal cortex is derived from the mesoderm and is formed from the coelomic epithelium close to the urogenital ridge as part of the adrenogenital primordium $^{6}$. In rats, the adrenogenital primordium is formed at gestational day (GD) 11. At that time, it is positive for SF-17. The primordial germ cells are transferred into the adrenogenital primordium at GD 12 , and the primordium divides into the adrenal primordium and reproductive primordium 
at GD 12.5 to $13.5^{7}$. By GD 18, two cortical zones are distinguishable in the adrenal cortical analogue: an outer zone of small basophilic cells (future zona glomerulosa) and an inner zone of large pale cells (future zona fasciculata) ${ }^{6,8}$. The adrenal medulla, which is derived from the ectoderm, is formed from the neural crest, and its transplantation into the adrenal primordium starts at GD 13.56. These cells later differentiate into chromaffin cells that form a definite medulla. At GD 16, chromaffin cell nests are scattered in the adrenal gland and gradually move to the central part of the cortex 9 . At postnatal days 3 to 7 , the medulla becomes a mass and differentiates from the cortex. Primary cells of the medulla differentiate either into chromaffin cells when induced by glucocorticoids or into neurons in the presence of nerve growth factors. There is no information available regarding the expression of nestin or NeuN in the differentiation stage of the adrenal medulla.

The cells with a spindle to polygonal shape and clear nucleus in the high cell density area were positive for nestin, a marker of immature neural cells, and negative for NeuN, a marker of mature neuronal cells. The expression of nervous system markers such as nestin and NeuN in the adrenal glands during the embryonic and postnatal stages is unknown, but these immunostaining results suggest that these cells are immature neural cells. In addition, because the small cells with round nuclei in the high cell density area were located in the adrenal gland and were morphologically similar to adrenal cortex cells and positive for SF-1, they were presumed to be adrenal cortex cells. These cells coexisted with immature nervous system cells that were positive for nestin, suggesting that they were immature adrenocortical cells. During the developmental stage of the rat adrenal gland, there is a period in which immature adrenal cortex cells are mixed with neural crest cells (future adrenal medulla cells), suggesting that the observed lesion was caused by developmental abnormality. When used as a term referring to malformation, dysplasia is defined as abnormal organization of cells into tissue and organs ${ }^{11}$, and therefore, this lesion was diagnosed as adrenal dysplasia. Since this lesion was composed of heterogeneous cells and their proliferative activity was low, neoplastic change was excluded. The cord structure of the fasciculata cells was disturbed, and cytoplasmic vacuolation, considered to be an accumulation of lipid droplets, was observed in the localized lesion. Consequently, the presence of an immature adrenocortical cell population might alter the blood flow and microenvironment in the normal adrenal cortex, resulting in accumulation of lipids, such as cholesterol, in the cytoplasm of adrenal cortex cells. This is presumed to trigger the formation of localized foci by mildly vacuolated adrenocortical cells surrounding immature adrenal cortex and neural cell populations.

We believe that this change also occurred under the condition of adrenal dysplasia in this rat. Since there have been no reports of dysplasia of the adrenal gland thus far, we believe that this report will provide useful information for toxicity evaluation of young rodents.

Disclosure of Potential Conflicts of Interest: The authors declare no conflicts of interest.

Acknowledgments: We thank Dr. Mitsuru Kuwamura from the Laboratory of Veterinary Pathology, Osaka Prefecture University, for staining the nestin antibody and Dr. Kiyokazu Ozaki from the Laboratory of Pathology, Setsunan University, for providing the SF-1 antibody.

\section{References}

1. Maitra A. The endocrine system, adrenal gland. In: Robbins and Cotran Pathologic Basis of Disease, 9th ed. V Kumar, A Abbas, and JC Aster (eds). Elsevier, Philadelphia. 1122-1135. 2015.

2. Brändli-Baiocco A, Balme E, Bruder M, Chandra S, Hellmann J, Hoenerhoff MJ, Kambara T, Landes C, Lenz B, Mense M, Rittinghausen S, Satoh H, Schorsch F, Seeliger F, Tanaka T, Tsuchitani M, Wojcinski Z, and Rosol TJ. Nonproliferative and proliferative lesions of the rat and mouse endocrine system. J Toxicol Pathol. 31(Suppl): 1S-95S. 2018. [Medline] [CrossRef]

3. Greaves P. Liver and pancreas. In: Histopathology of Preclinical Toxicity Studies, 4th ed. Elsevier, San Diego. 740761. 2012.

4. Nyska A, and Maronpot RR. Adrenal gland. In: Pathology of the Mouse. RR Maronpot, GA Boorman, and BW Gaul (eds). Cache River Press, Vienna, Illinois. 509-536. 1999.

5. Beamer WG, Sweet HO, Bronson RT, Shire JG, Orth DN, and Davisson MT. Adrenocortical dysplasia: a mouse model system for adrenocortical insufficiency. J Endocrinol. 141: 33-43. 1994. [Medline] [CrossRef]

6. Furukawa S, Nagaike M, and Ozaki K. Databases for technical aspects of immunohistochemistry. J Toxicol Pathol. 30: 79-107. 2017. [Medline] [CrossRef]

7. Walling BE, Picut CA, and Remick AK. The endocrine system. In: Atlas of Histology of the Juvenile Rat. GA Parker, and CA Picut (eds). Elsevier, San Diego. 257-291. 2016.

8. Hatano O, Takakusu A, Nomura M, and Morohashi K. Identical origin of adrenal cortex and gonad revealed by expression profiles of Ad4BP/SF-1. Genes Cells. 1: 663-671. 1996. [Medline] [CrossRef]

9. Mitani F, Mukai K, Miyamoto H, Suematsu M, and Ishimura Y. Development of functional zonation in the rat adrenal cortex. Endocrinology. 140: 3342-3353. 1999. [Medline] [CrossRef]

10. Lever JD. Adreno-cortical histogenesis in the rat: with observations on lipid and ascorbic acid distribution. J Anat. 89: 293-300. 1955. [Medline]

11. Jorgenson RJ. Perspective on the classification of ectodermal dysplasia. Am J Med Genet A. 149A: 2057-2061. 2009. [Medline] [CrossRef] 